\title{
MORPHOLOGICAL DIFFERENTIATION OF POLYGONUM VIVIPARUM (POLYGONACEAE) IN EUROPEAN POPULATIONS
}

\author{
KATARZYNA MARCYSIAK
}

\begin{abstract}
The variation of Polygonum viviparum L. in Europe was studied in 584 plants sampled from 14 populations at different altitudes and from different substrates in the Carpathians, Alps, Dinaric Alps, Pyrenees and Scandinavian Mts. The samples were analyzed biometrically, using 12 measured stem and inflorescence characters and 10 characters calculated from those 12 . The obtained ranges of values were only slightly wider than those given in the literature. All characters significantly differed between populations and six characters were statistically significant in identifying differences between regions. Altitude, substrate and the interactions between them significantly affected the differences in characters between samples. The values of most of the measured characters were lower in samples from higher locations and on poor substrate than in those from lower localities and on rich substrate. Substrate type affected the calculated characters less but it influenced the shift between vegetative and generative reproduction. Multidimensional analyses confirmed the proximity of samples from regions either geographically close or linked via routes of postglacial migrations, despite altitude and substrate differences between them.
\end{abstract}

Key words: arctic-alpine plants, biogeography, biometry, plant morphology, plant variation, vegetative reproduction

Katarzyna Marcysiak, Department of Botany, Kazimierz Wielki University, Ossolinskich 12, 85-093 Bydgoszcz, Poland; e-mail: marc@ukw.edu.pl

\section{INTRODUCTION}

Polygonum viviparum L. (Polygonaceae) is a circumpolar arctic-alpine plant (Zając \& Zając 2009). It is a perennial geophyte with short rhizomes giving rise to erect unbranched leafy stems with slender inflorescence spikes at the top (Pawłowski 1956; Webb \& Chater 1964). The species is known for its frequent asexual - 'viviparous' - reproduction by bulbils formed in place of flowers (Wookey et al. 1994). The bulbils are red or brown, a character apparently not associated with any other traits of the plant (Dormann et al. 2002). Despite the dominance of vegetative propagation, medium to high genetic diversity has been recorded in alpine and subarctic populations from Europe (Law et al. 1983; Bauert 1993, 1996) and the Rocky Mountains (Diggle et al. 1998). Its seeds are recorded only occasionally, primarily due to a low fertilization rate and abortion of young sporophytes (Diggle et al. 2002), but its seed production is enough to maintain the observed genetic diversity (Diggle et al. 1998).
The species is tolerant to $\mathrm{CaCO}_{3}$ and to $\mathrm{pH}$ from 6.5 to 9.0 , but its occurrence is limited to harsh climatic conditions; it grows in arctic tundra or in the (subalpine) alpine zone in mountains, on meadows and open areas (Wookey et al. 1994; Diggle 1997; Diggle et al. 1998; Totland \& Nyléhn 1998).

Several studies have described the effect of the environment on P. viviparum morphology. Warmer conditions appear to have only a weak or even no influence on the width of the largest leaf on the stem or on the number of flowers and bulbils (Totland \& Nyléhn 1998; Gugerli \& Bauert 2001). In one study, experimentally increased mean temperature did not influence vegetative parameters significantly but caused allocation of biomass to reproductive structures (Wookey et al. 1994). In plants grown under experimentally increased temperature in open-top chambers, bulbil biomass and flowering stem height were increased (Gugerli $\&$ Bauert 2001). The overall impact of temperature on plants is difficult to assess, particularly in cold 
climates. Chapin III (1983) concluded that temperature does not strongly limit plant growth in the Arctic. It is generally known that in the mountains of Central Europe plant size decreases with altitude (Fabbro \& Körner 2004), and this has been confirmed for Polygonum viviparum (Bauert 1993).

Allocation of biomass to reproductive organs is a very important parameter for plants. Polygonum viviparum shows a trade-off between sexual and asexual reproduction reflected in a negative correlation between number of flowers and number of bulbils (Totland \& Nyléhn 1998). The results for these traits are ambiguous, however: an increase in allocation to vegetative reproduction with increasing altitude has been reported in Polygonum viviparum from the Swiss Alps (Bauert 1993), but in the Qinghai-Tibet Plateau sexual reproduction increased with elevation (Fan \& Yang 2009). It has also been suggested that growing season length influences the mode of reproduction: in the mountains of southern Japan, the ratio of flowers to bulbils was found to be smaller in plants from places where snow melted later (Tomita \& Masuzawa 2010).

The present European arctic-alpine range of Polygonum vivparum arose as a consequence of glacial and postglacial migrations. The observed intraspecific variability of arctic-alpine plants is the result of these migrations, and recent molecular studies of this variability have revealed the phylogeography of several arctic-alpine species (Skrede et al. 2006; Schönswetter et al. 2007; Alsos et al. 2009). The question of whether this isolation leads to variability on the morphological level is much less well investigated. Recent research on the morphological diversity of two arctic-alpine plants (Salix herbacea, $S$. reticulata) within their European range indicated that the biogeographic structure of this variation was consistent with existing proposals for pathways of the plants' migrations (Marcysiak 2012a, b).

Current findings on the biogeography of arcticalpine species and the above-mentioned studies suggest a number of working hypotheses for this study, formulated below.

Populations of $P$. viviparum from isolated mountain ranges should show morphological dif- ferences. The differences should be greater between more distant massifs than between populations connected with migration routes. Environmental factors may influence species morphology, so plants from populations growing in the subalpine zone should be larger than those from the alpine zone, substrate rich in calcium (limestone, schist) should positively affect plant size, environmental factors should have a stronger effect on the size of the plant and its parts than on its shape, and a trade-off between vegetative and generative reproduction should be evident.

\section{MATERIAL AND METHODS}

\section{MATERIAL AND MEASUREMENTS}

Fourteen samples each consisting of 19-55 complete flowering stems of $P$. viviparum, provided a total of 584 individuals (Table 1). Plants growing more than three meters apart were sampled to minimize the possibility of collecting the same genet. The sampled populations grew on limestone, granite or schist at sites in distant regions: the Southern Carpathians (CS), Western Carpathians (CW), Central Alps (AC), Northern Alps (AN), Western Alps (AW) Dinaric Alps (AD), Pyrenees (P) and Scandinavian Mountains (SW) (Fig. 1). The plant material was dried and is preserved in the herbarium of the Department of Botany, Kazimierz Wielki University in Bydgoszcz, Poland.

For analyses, samples were divided into groups with regard to substrate and altitudinal zone: $\mathrm{P}$ - growing on poor granite bedrock, $\mathrm{R}$ - growing on substrate rich in calcium (limestone or schist); and SA - growing in subalpine zone, A - growing in alpine zone (Table 1). The 22 analyzed characters (Table 2) were selected specifically for the study, some following already published data on the diversity of $P$. viviparum (Law et al. 1983; Bauert 1993; Totland \& Nyléhn 1998; Gugerli \& Bauert 2001; Fan \& Yang 2009). Measurements were taken from dried plants with the use of standard graph paper. Character values (means $\pm \mathrm{SD}$ ) are in APPENDIX 1 .

\section{ANALYSES}

The unimodality of data was assessed with frequency histograms, then descriptive statistics were calculated for the entire data set, for regions, for particular samples and for groups of samples (SA, A, P, R). The level of character variation was tested with variation coefficients $(\mathrm{Cv}=100 \mathrm{SD} / \mathrm{M})$, separately for the whole data set, dis- 
Table 1. Collection data for the studied Polygonum viviparum L. populations. SA - subalpine; A - alpine, P - poor, granite substrate; $\mathrm{R}$ - substrate rich in calcium

\begin{tabular}{|c|c|c|c|c|c|c|c|}
\hline Location of population & $\begin{array}{c}\text { Acro- } \\
\text { nym }\end{array}$ & $\begin{array}{l}\text { Number } \\
\text { of indi- } \\
\text { viduals }\end{array}$ & $\begin{array}{l}\text { Altitude } \\
{[\mathrm{m} \text { a.s.1. }]}\end{array}$ & $\begin{array}{l}\text { Altitu- } \\
\text { dinal } \\
\text { zone }\end{array}$ & Substrate & $\begin{array}{l}\mathrm{N} \\
{\left[{ }^{\circ}\right]}\end{array}$ & $\begin{array}{c}\mathrm{E} \\
{\left[{ }^{\circ}\right]}\end{array}$ \\
\hline Southern Carpathians, Romania, Parâng Mts. & $\mathrm{CS}$ & 19 & 2390 & A & $\mathrm{P}$ & 42.354 & 23.524 \\
\hline $\begin{array}{l}\text { Western Carpathians, Poland, Tatra Mts., Kondracka } \\
\text { Przełęcz }\end{array}$ & CW1 & 50 & 1700 & SA & $\mathrm{R}$ & 49.263 & 19.954 \\
\hline Western Carpathians, Slovak Rep., Tatra Mts., Rysy & $\mathrm{CW} 2$ & 19 & 2130 & A & $\mathrm{P}$ & 49.174 & 20.079 \\
\hline Dinaric Mountains, Montenegro, Komovi massif & $\mathrm{AD}$ & 28 & 2345 & A & $\mathrm{R}$ & 42.687 & 19.669 \\
\hline Central Alps, Austria, Oetztal, Obergurgl & $\mathrm{AC} 1$ & 44 & 2042 & SA & $\mathrm{P}$ & 46.880 & 11.041 \\
\hline Central Alps, Austria, Oetztal, Kreuz Kogel & $\mathrm{AC} 2$ & 50 & 2300 & SA & $\mathrm{P}$ & 46.842 & 10.895 \\
\hline Central Alps, Austria, Oetztal, Gaislacher Kogel & $\mathrm{AC} 3$ & 49 & 2820 & A & $\mathrm{P}$ & 46.939 & 10.969 \\
\hline Northern Alps, Austria, Grubigstein & AN & 53 & 2100 & A & $\mathrm{R}$ & 47.382 & 10.842 \\
\hline France, Western Alps, Col du Galibier & AW & 33 & 2620 & A & $\mathrm{R}$ & 42.056 & 6.405 \\
\hline Andorra, Pyrenees, Rialb & $\mathrm{P} 1$ & 34 & 2330 & SA & $\mathrm{R}$ & 42.636 & 1.568 \\
\hline Andorra, Pyrenees, Arcalis & $\mathrm{P} 2$ & 54 & 2600 & A & $\mathrm{P}$ & 42.617 & 1.485 \\
\hline Andorra, Pyrenees, Casamanya & P4 & 46 & 2700 & A & $\mathrm{R}$ & 42.584 & 1.568 \\
\hline Andorra, Pyrenees, Casamanya & P3 & 50 & 2700 & A & $\mathrm{R}$ & 42.584 & 1.568 \\
\hline Norway, Hardangevidda, Hallingskarvet & SW & 55 & 1300 & SA & $\mathrm{R}$ & 60.559 & 8.079 \\
\hline
\end{tabular}

tinguished regions, site groups and particular samples. To find highly related or redundant traits, correlations between character values within the whole data set were assessed using Pearson's correlation coefficient.

Student's $t$ test was performed to compare pairs of groups SA-A and P-R to find the characters differing significantly between groups. Univariate analysis of variance (ANOVA/ANCOVA) was performed to assess the significance of differences between samples. The level of difference between regions and between samples within regions was determined by nested ANOVA. Two-way ANOVA was used to examine the effects of substrate type, altitude zone, and the interaction between them. The results of this variance analysis are given in least squares means charts (Sokal \& Rolf 2003).

Discriminant analysis was performed to determine multidimensional relations between samples (Sokal \& Rohlf 2003). Under the assumption that the calculated characters are more stable and less sensitive to external factors (Marcysiak 2012c), they were used as the basis of this analysis.

\section{RESULTS}

The stem of $P$. viviparum was $c a 143 \mathrm{~mm}$ long and had 2.72 leaves on average. The upper leaf was $17.5 \mathrm{~mm}$ long and $2.3 \mathrm{~mm}$ wide, and the biggest leaf $29 \mathrm{~mm}$ long and $5.6 \mathrm{~mm}$ wide. Some plants from the Central and Northern Alps were devoid of the small upper leaf. The biggest leaf petiole (blp) was $9.9 \mathrm{~mm}$ long on average and was present on all plants from CS, AD, CW2, WA, P2 and P4. In the other samples, blp was missing from $2-34 \%$ of individuals. Of the 584 plants, 560 possessed the upper leaf (24 did not), only 131 individuals pos-

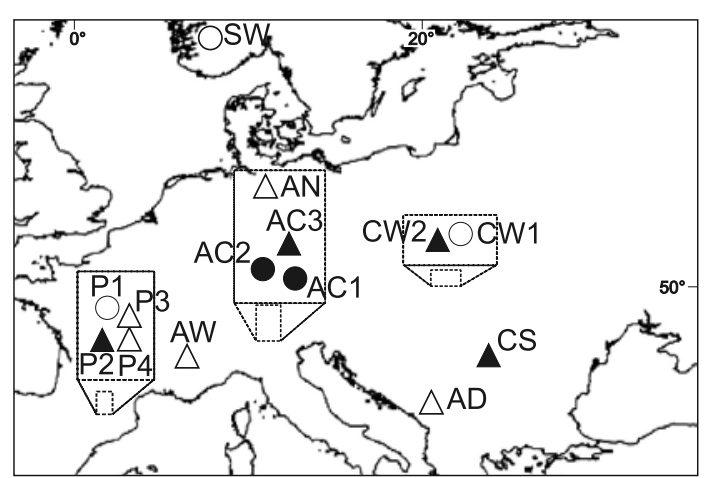

Fig. 1. Location of Polygonum viviparum L. samples; triangles - alpine zone; circles - subalpine zone; black - samples collected from poor granite substrate; white - samples collected from calcium-rich substrate. $\mathrm{CS}$ - Southern Carpathians CW - Western Carpathians, AD - Dinaric Alps, AC - Central Alps, AN - Northern Alps, AW - Western Alps, P - Pyrenees, SW - Scandinavian Mountains. 
Table 2. Analyzed characters of Polygonum viviparum L. and their statistical characteristics.

\begin{tabular}{|c|c|c|c|c|c|c|}
\hline $\begin{array}{l}\text { Character } \\
\text { category }\end{array}$ & Character & Acronym & M & Min & Max & $\mathrm{Cv}$ \\
\hline \multirow{7}{*}{$\begin{array}{l}\text { Measured char- } \\
\text { acters of stem } \\
\text { and leaves }\end{array}$} & Length of stem $[\mathrm{mm}]$ & stl & 143.15 & 28.00 & 396.00 & 40.86 \\
\hline & Number of leaves on stem & $\ln$ & 2.72 & 1.00 & 5.00 & 24.72 \\
\hline & Length of upper leaf blade [mm] & ull & 17.47 & 2.00 & 66.00 & 55.13 \\
\hline & Width of upper leaf blade [mm] & $u l w$ & 2.26 & 1.00 & 15.00 & 73.65 \\
\hline & Length of biggest leaf blade $[\mathrm{mm}]$ & bll & 29.41 & 3.00 & 71.00 & 35.77 \\
\hline & Width of biggest leaf blade [mm] & blw & 5.66 & 1.00 & 26.00 & 51.92 \\
\hline & Petiole length of biggest leaf [mm] & blp & 9.91 & 1.00 & 43.00 & 74.29 \\
\hline \multirow{6}{*}{$\begin{array}{l}\text { Calculated } \\
\text { characters of } \\
\text { stem and leaves }\end{array}$} & Number of leaves/stem length & $\ln / s t l$ & 0.02 & 0.01 & 0.11 & 56.36 \\
\hline & Length of upper leaf blade/stem length & ull/stl & 0.13 & 0.01 & 0.52 & 52.94 \\
\hline & Length/width of upper leaf & ull/ulw & 8.71 & 0.47 & 33.00 & 42.33 \\
\hline & Length of biggest leaf blade/stem length & bll/stl & 0.23 & 0.02 & 0.72 & 42.80 \\
\hline & Length/width of biggest leaf & $\mathrm{bll} / \mathrm{blw}$ & 6.23 & 0.31 & 21.00 & 53.28 \\
\hline & Proportion of petiole in biggest leaf length & blp/bllp & 0.25 & 0.02 & 0.77 & 55.74 \\
\hline \multirow{5}{*}{$\begin{array}{l}\text { Measured and } \\
\text { counted charac- } \\
\text { ters of spike }\end{array}$} & Length of spike $[\mathrm{mm}]$ & $s p l$ & 34.94 & 10.00 & 84.00 & 40.78 \\
\hline & Length of part of spike with bulbils [mm] & $s p-b l$ & 28.70 & 5.00 & 83.00 & 42.87 \\
\hline & Number of flowers & $f n$ & 7.05 & 0.00 & 50.00 & 142.73 \\
\hline & Number of bulbils & $b n$ & 27.16 & 2.00 & 86.00 & 42.55 \\
\hline & Number of flower and bulbils & $f b n$ & 34.25 & 4.00 & 86.00 & 36.72 \\
\hline \multirow{4}{*}{$\begin{array}{l}\text { Calculated } \\
\text { characters of } \\
\text { spike }\end{array}$} & Spike length/stem length & $\mathrm{spl} / \mathrm{stl}$ & 25.60 & 10.24 & 80.00 & 29.06 \\
\hline & Number of bulbils/number of flowers and bulbils & $b n / f b n$ & 0.82 & 0.09 & 1.00 & 27.85 \\
\hline & $\begin{array}{l}\text { Number of bulbils/length of part of spike with } \\
\text { bulbils }\end{array}$ & $b n / s p b l$ & 0.99 & 0.07 & 2.36 & 31.48 \\
\hline & Number of flowers and bulbils/length of spike & $\mathrm{fbn} / \mathrm{spl}$ & 1.02 & 0.12 & 2.33 & 27.14 \\
\hline
\end{tabular}

sessed the upper leaf petiole, and 512 possessed the biggest leaf petiole. The spike was almost $35 \mathrm{~mm}$ long and yielded 27 bulbils and 7 flowers on average. Sample CA2 did not have any flowers on the spikes. The share of specimens lacking flowers in particular samples ranged from $2 \%$ to $60 \%$; 339 individuals had flowers on the spikes.

Analysis of the frequency histograms confirmed that the distributions of the analyzed characters in the whole data set were similar to normal but slightly right-skewed and narrow. This trend was evident for the whole set of data, for particular regions, altitudinal and site groups (data not shown).

The $\mathrm{Cv}$ values calculated for the whole data set were highest for $f n, u l w$ and $b l p$, and most stable for $l n, f b n / s p l$ and $b n / f b n$ (Table 2).

Many of the characters depended on each other and these relationships varied between the examined populations. Correlations between stl and $l n / s t l$, blp and $b l p / b l l p$ or $s p l$ and $s p-b l$ were most common in the analyzed data set. The most frequent linkages were those between stem length $(s t l)$ and spike length $(s p l)$, all the measured characters pertaining to them, and the characters calculated from them (Table 3 ).

Certain character values were similar between some of the regions. Plants from the Western Carpathians $(\mathrm{CW})$, Dinaric Alps (AD) and Western Alps (AW) were tallest, and those from the Central and Northern Alps (AC, AN), Pyrenees (P) and Southern Carpathians (CS) were smaller (Fig. 2).

The groups connected with altitudinal zones SA-A differed significantly with regard to 16 characters, both measured and calculated, but the differences between groups of substrate type P-R were related mainly to measured characters (Table 4).

ANOVA indicated that all the characters differed significantly between populations (not shown). Nested ANOVA showed that variation 


\begin{tabular}{|c|c|c|c|c|c|c|c|c|c|c|c|c|c|c|c|c|c|c|c|c|c|}
\hline $1 q d s / u q$ & & & & & & & & & & & & & & & & & & & & & $\frac{\pi}{2}$ \\
\hline$u q f / u q$ & & & & & & & & & & & & & & & & & & & & $\begin{array}{l}0 \\
\dot{0} \\
\dot{0}\end{array}$ & 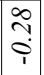 \\
\hline$\not 1 s / 1 d s$ & & & & & & & & & & & & & & & & & & & $\underset{i}{\grave{i}}$ & $\begin{array}{l}n \\
\stackrel{0}{0}\end{array}$ & $\frac{1}{0}$ \\
\hline$u q f$ & & & & & & & & & & & & & & & & & & $\frac{0}{0}$ & $\frac{n}{2}$ & $\begin{array}{l}\stackrel{0}{0} \\
\dot{0}\end{array}$ & $\tilde{n}$ \\
\hline$u q$ & & & & & & & & & & & & & & & & & ? & $\begin{array}{l}n \\
0 \\
0 \\
1\end{array}$ & $\hat{z}$ & 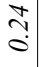 & $\stackrel{m}{0}$ \\
\hline uf & & & & & & & & & & & & & & & & $\frac{ \pm}{\stackrel{ \pm}{0}}$ & $\frac{1}{2}$ & $\stackrel{\imath}{\tilde{c}}$ & $\mid \begin{array}{l}\infty \\
\infty \\
0 \\
1\end{array}$ & $\begin{array}{l}0 \\
0 \\
0 \\
\dot{1}\end{array}$ & $\tilde{n}$ \\
\hline $19-d s$ & & & & & & & & & & & & & & & Õ & 我 & $\stackrel{2}{2}$ & $\stackrel{0}{0}$ & ָे & $\begin{array}{l}\hat{z} \\
\stackrel{i}{i}\end{array}$ & $\frac{n}{1}$ \\
\hline$l^{d s}$ & & & & & & & & & & & & & & $\hat{a}$ & 2 & $\stackrel{n}{2}$ & $\hat{\Omega}$ & $\begin{array}{l}\infty \\
\\
0\end{array}$ & $\begin{array}{l}0 \\
1 \\
1 \\
1\end{array}$ & $\frac{7}{i}$ & $\begin{array}{c}n \\
\vdots \\
1\end{array}$ \\
\hline$d_{11 q / d_{1 q}}$ & & & & & & & & & & & & & $\begin{array}{l}0 \\
0 \\
\end{array}$ & $\begin{array}{l}\hat{0} \\
\dot{0}\end{array}$ & $\stackrel{\circ}{\circ}$ & $\stackrel{0}{0}$ & $\stackrel{0}{\overrightarrow{0}}$ & $\begin{array}{l}\infty \\
0 \\
0 \\
1\end{array}$ & $\begin{array}{l}n \\
0 \\
0 \\
1\end{array}$ & $\frac{ \pm}{0}$ & 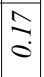 \\
\hline$m / 9 / 119$ & & & & & & & & & & & & $\stackrel{n}{1}$ & $\stackrel{\overbrace{}}{0}$ & $=$ & $\tilde{r}$ & O̊ & $\frac{2}{0}$ & $\stackrel{2}{\check{c}}$ & $\begin{array}{l}\stackrel{\imath}{1} \\
\tilde{1} \\
i\end{array}$ & $\frac{n}{\dddot{0}}$ & $\begin{array}{l}0 \\
0 \\
0 \\
0\end{array}$ \\
\hline $17 s / 119$ & & & & & & & & & & & సे & ָ̃ & సે & $\begin{array}{l}0 \\
0 \\
0 \\
1\end{array}$ & $\stackrel{+}{0}$ & 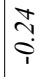 & 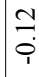 & : & $\frac{\infty}{-1}$ & $\begin{array}{l}0 \\
\\
0\end{array}$ & 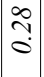 \\
\hline м $/ n / l 1 n$ & & & & & & & & & & O̦ & $\underset{0}{\tilde{0}}$ & ¿̊. & $\tilde{m}$ & $\frac{9}{0}$ & $\begin{array}{l}0 \\
\\
0\end{array}$ & $\frac{m}{0}$ & $\stackrel{n}{0}$ & $\frac{ \pm}{0}$ & $\frac{0}{2}$ & $\begin{array}{l}0 \\
0 \\
\dot{1} \\
1\end{array}$ & $\begin{array}{l}0 \\
0 \\
0\end{array}$ \\
\hline$\not 1 s / 1 l^{n}$ & & & & & & & & & $\widehat{\hat{\sigma}}$ & $\underset{\sim}{\infty}$ & $\begin{array}{l}n \\
0 \\
0\end{array}$ & $\exists$ & 合 & $\begin{array}{l}= \\
\\
\end{array}$ & $\stackrel{0}{0}$ & $\begin{array}{l}\infty \\
0 \\
0 \\
0\end{array}$ & $\begin{array}{l}\text { O } \\
0 \\
0\end{array}$ & $\hat{\jmath}$ & $\begin{array}{l}n \\
0 \\
0 \\
1\end{array}$ & $\begin{array}{l}\infty \\
0 \\
0 \\
0\end{array}$ & ठ্. \\
\hline$\not \neg S / u\rceil$ & & & & & & & & $\frac{\infty}{0}$ & $\stackrel{ \pm}{\dot{I}}$ & $\stackrel{7}{8}$ & $\begin{array}{l}0 \\
0 \\
0 \\
\end{array}$ & $\stackrel{1}{\circ}$ & iñ & ñ & $\frac{0}{0}$ & i & 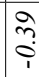 & $\stackrel{0}{2}$ & $\begin{array}{l}0 \\
0 \\
0 \\
1\end{array}$ & $\hat{n}$ & $\stackrel{m}{0}$ \\
\hline$d_{1} q$ & & & & & & & $\frac{ \pm}{\dot{0}}$ & oे & $\stackrel{\infty}{0}$ & $\stackrel{ \pm}{\dot{I}}$ & $\begin{array}{l}\tilde{n} \\
0 \\
1\end{array}$ & $\stackrel{\infty}{\infty}$ & $\widehat{\check{c}}$ & $\frac{m}{0}$ & ָे & $\frac{\infty}{0}$ & ?̊ & 命 & $\frac{a}{a}$ & $\begin{array}{l}\infty \\
0 \\
0 \\
0\end{array}$ & $\stackrel{0}{0}$ \\
\hline m/q & & & & & & $\stackrel{7}{8}$ & $\frac{ \pm}{\dot{0}}$ & $\stackrel{+}{0}$ & $\begin{array}{l}n \\
0 \\
0\end{array}$ & $\begin{array}{l}0 \\
0 \\
0 \\
\end{array}$ & مْ & ?̊ & $\frac{n}{0}$ & $\stackrel{0}{\circ}$ & $=$ & $\frac{N}{3}$ & $\frac{1}{0}$ & ก̦ & $\begin{array}{l}1 \\
0 \\
0 \\
1\end{array}$ & $\begin{array}{c}\stackrel{0}{\circ} \\
\dot{0}\end{array}$ & $\stackrel{0}{\circ}$ \\
\hline 119 & & & & & $\stackrel{n}{\tilde{c}}$ & $\frac{\infty}{0}$ & $\underset{1}{\stackrel{7}{0}}$ & $\begin{array}{l}n \\
0 \\
0\end{array}$ & $\check{\check{\gamma}}$ & $\stackrel{\overbrace{}}{\sim}$ & ڤે & $\underset{1}{\tilde{c}}$ & ?̊ & $\stackrel{8}{8}$ & $\overline{0}$ & $\underset{\overbrace{}}{0}$ & ? & $\begin{array}{l}n \\
0 \\
0 \\
1\end{array}$ & $\hat{\tilde{N}}$ & $\begin{array}{l}\vec{\prime} \\
\dot{0} \\
\end{array}$ & $\begin{array}{l}\overline{0} \\
0 \\
\end{array}$ \\
\hline nүn & & & & $\overline{0}$ & 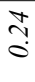 & $\frac{\infty}{0}$ & oे & 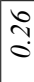 & $\hat{n}$ & $\frac{\sim}{\rho}$ & 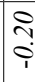 & $\stackrel{n}{\circ}$ & $=$ & $\stackrel{0}{\stackrel{1}{0}}$ & $\stackrel{+}{0}$ & $\stackrel{\circ}{\circ}$ & $\stackrel{g}{\circ}$ & $\frac{n}{7}$ & $\overrightarrow{0}$ & $\begin{array}{l}\overrightarrow{0} \\
\dot{0}\end{array}$ & ro. \\
\hline $1 l^{n}$ & & & $\stackrel{n}{\Delta}$ & $\stackrel{\infty}{m}$ & 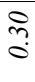 & $\stackrel{n}{2}$ & $\underset{1}{7}$ & $\stackrel{7}{0}$ & $\tilde{n}$ & $\underset{\Upsilon}{\tilde{\gamma}}$ & $\begin{array}{l}n \\
0 \\
0\end{array}$ & $\frac{0}{0}$ & 过 & $\stackrel{+}{m}$ & $\stackrel{\infty}{\sim}$ & $\stackrel{1}{1}$ & $\stackrel{?}{\stackrel{+}{0}}$ & ○. & $\frac{1}{0}$ & $=$ & ọ \\
\hline$u l$ & & $\frac{b}{i}$ & $\begin{array}{l}\infty \\
0 \\
0\end{array}$ & $\frac{n}{0}$ & $\frac{m}{0}$ & $\stackrel{\dddot{n}}{\tilde{c}}$ & ? & $\frac{N}{0}$ & $\stackrel{\infty}{\circ}$ & $\underset{\overbrace{}}{\tilde{c}}$ & $\begin{array}{l}\overrightarrow{0} \\
\dot{0}\end{array}$ & $\stackrel{\infty}{0}$ & O. & 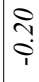 & $\stackrel{\dddot{c}}{\tilde{c}}$ & Ô. & $\frac{n}{0}$ & đo & $\begin{array}{l}a \\
\grave{1} \\
i\end{array}$ & $\begin{array}{l}0 \\
\sim \\
0 \\
0\end{array}$ & $\stackrel{\overbrace{}}{\grave{0}}$ \\
\hline pls & $\begin{array}{l}\dot{J} \\
\stackrel{0}{0}\end{array}$ & $\stackrel{\circ}{\circ}$ & $\stackrel{ \pm}{\stackrel{\Delta}{0}}$ & $\stackrel{n}{\circ}$ & mె & $\stackrel{?}{0}$ & $\begin{array}{l}\infty \\
0 \\
0\end{array}$ & 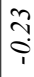 & $\frac{n}{0}$ & ? & $\stackrel{1}{2}$ & $\begin{array}{l}\Omega \\
0\end{array}$ & $\stackrel{n}{0}$ & rூ & $\stackrel{\tilde{2}}{0}$ & $\stackrel{n}{2}$ & ? & $\hat{n}$ & $\begin{array}{l}0 \\
0 \\
\dot{1}\end{array}$ & $\hat{\tilde{c}}$ & $\overrightarrow{\tilde{n}}$ \\
\hline Іәџ૦Е.ЕЧО & $\Xi$ & ミ & $\frac{3}{3}$ & $\lesssim$ & $\stackrel{5}{0}$ & 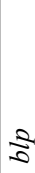 & $\begin{array}{l}\frac{\pi}{n} \\
\equiv\end{array}$ & $\underset{\Xi}{\stackrel{\varpi}{\Xi}}$ & $\underset{\vdots}{\stackrel{\vdots}{\vdots}}$ & $\underset{\lesssim}{\approx}$ & $\underset{\vdots}{\vdots}$ & 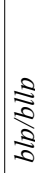 & $\overline{\frac{\pi}{2}}$ & $\frac{\pi}{1}$ & $\Sigma$ & $\Xi$ & 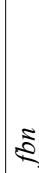 & $\frac{\pi}{\frac{\pi}{\pi}}$ & $\frac{5}{5}$ & $\begin{array}{l}\text { हे } \\
\text { है } \\
\vdots\end{array}$ & $\begin{array}{c}\overline{\tilde{n}} \\
\bar{\delta} \\
0\end{array}$ \\
\hline
\end{tabular}



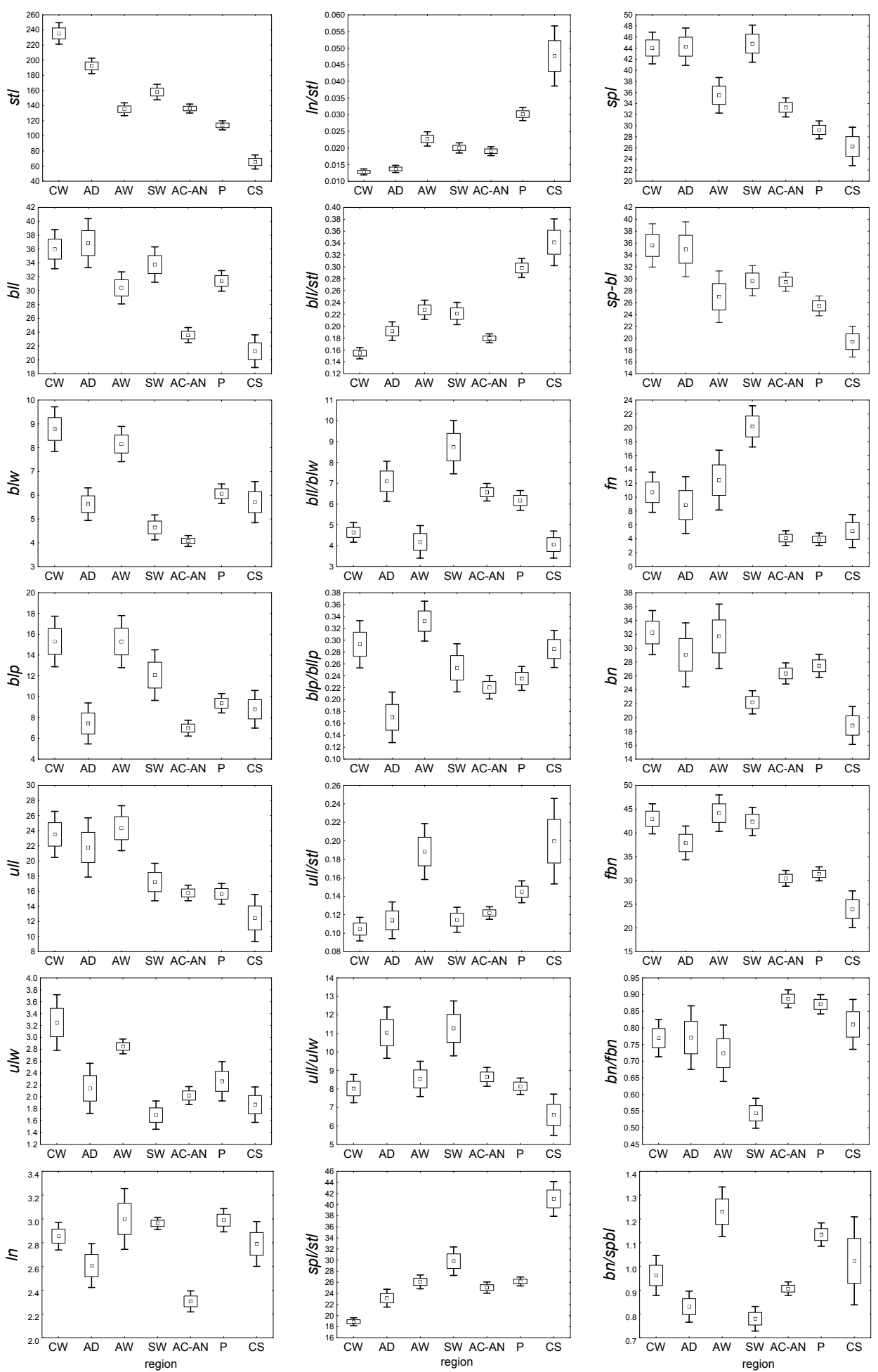

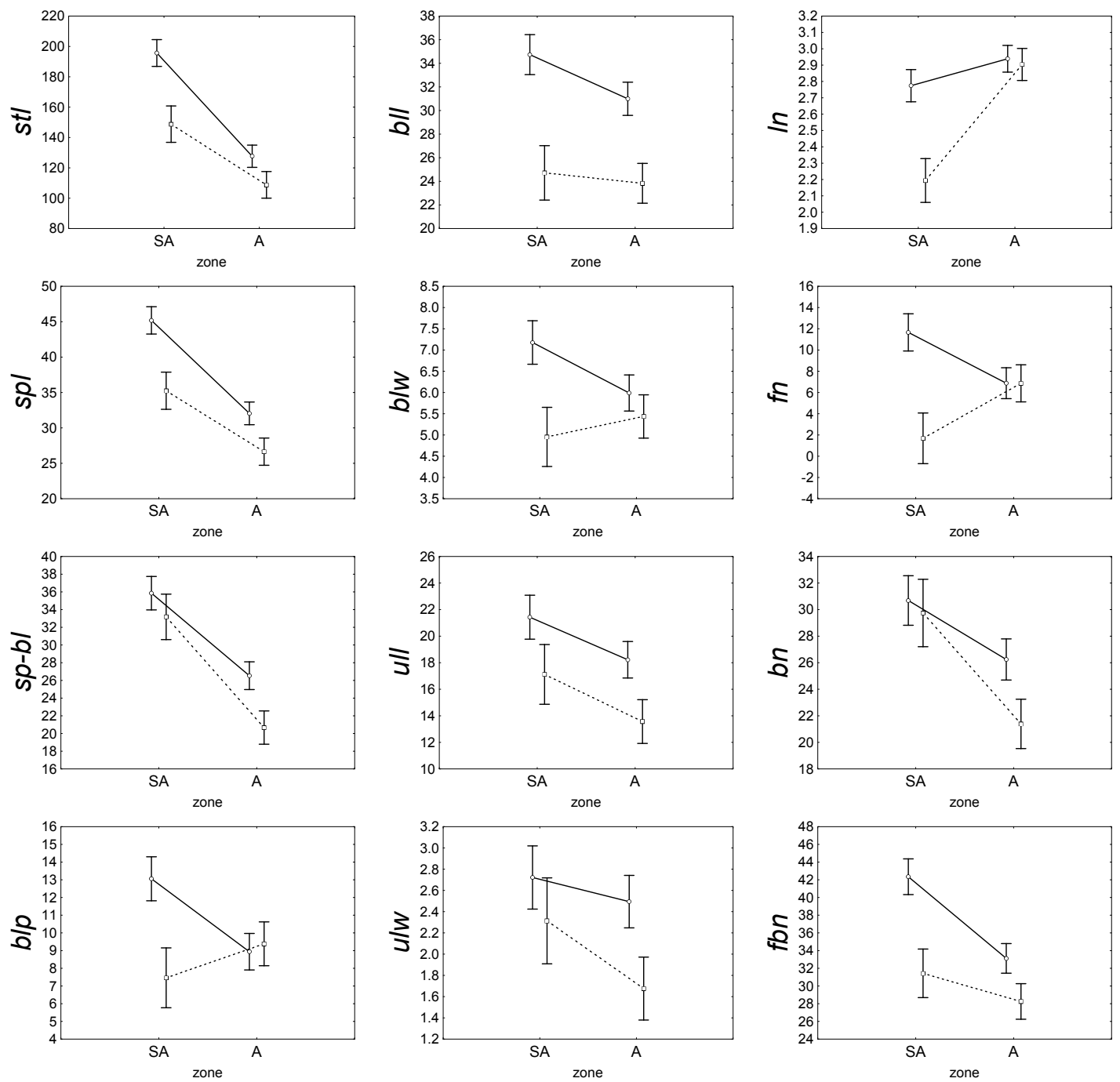

Fig. 3. ANOVA results - interaction between altitude and substrate group for measured and calculated characters of Polygonum viviparum L., based on least square means; SA - alpine zone; A - alpine zone; dashed line - samples collected from poor granite substrate; solid line - samples collected from calcium-rich substrate; character abbreviations as in Table 2.

was highest within samples, that is, large differences between individual plants in the samples (Table 5). Six characters significantly distinguished regions; the percentage of variance of these characters (bll, blw, blp, ull/stl, spl/stl, bn/spbl) was greater between regions than between populations within regions.

Altitudinal zone had a stronger effect than substrate type on the differences between characters, and the interaction between the two factors affected

Fig. 2. Mean values for characters of Polygonum viviparum L. for regions: CW - Western Carpathians, AD - Dinaric Alps, AW - Western Alps, SW - Scandinavian Mountains, AC-AN - Central and Northern Alps, P - Pyrenees, CS - Southern Carpathians; character acronyms as in Table 2; point - arithmetic mean; box - standard error; whiskers - 1.96 standard error. 

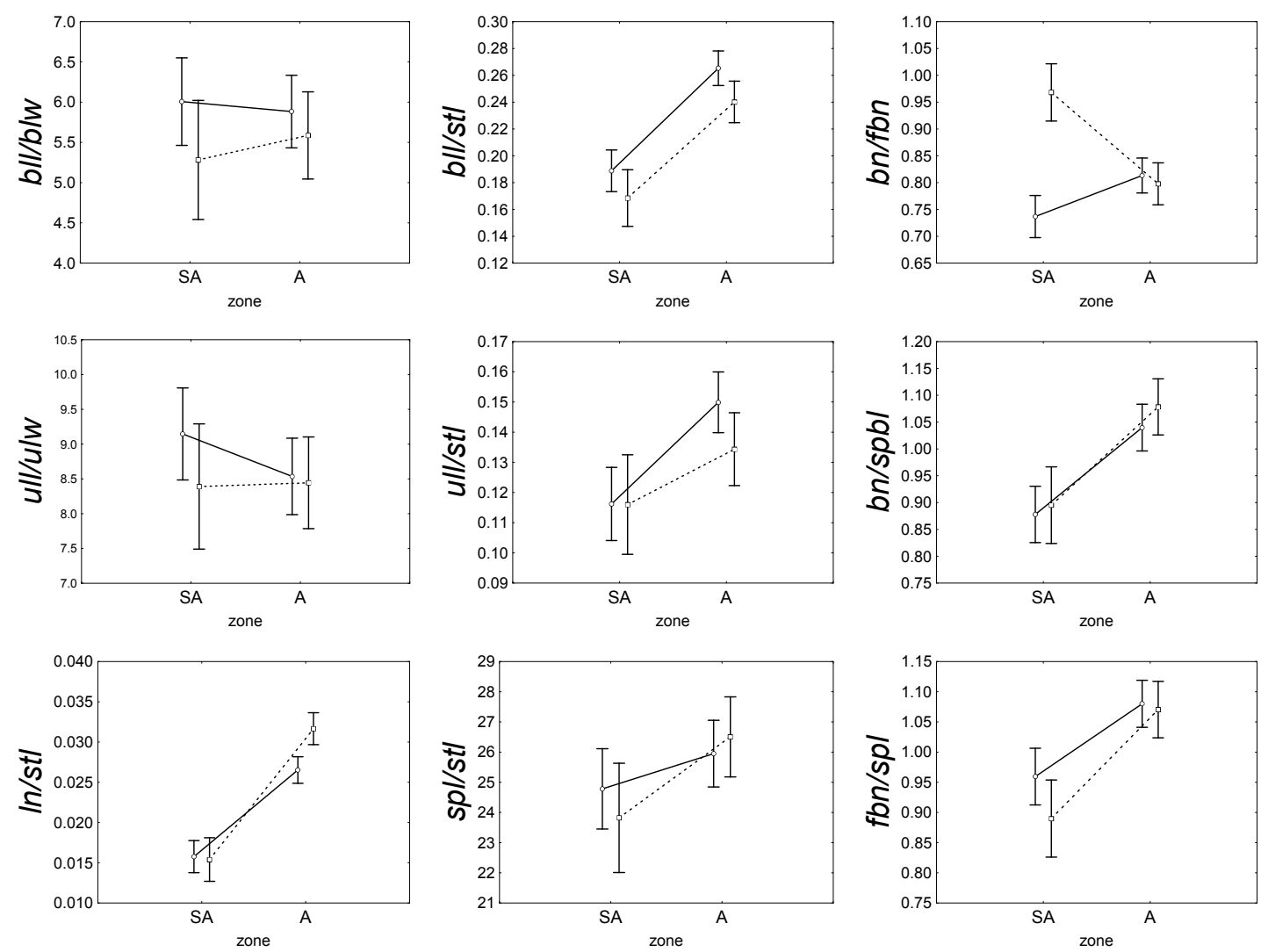

Fig. 4. ANOVA results - graphs of interaction between altitude and substrate groups for calculated characters of Polygonum viviparum L., based on least square means; SA - alpine zone; A - alpine zone; dashed line - samples collected from poor granite substrate; solid line - samples collected from calcium-rich substrate; character abbreviations as in Table 2.

the characters the least. The values of most of the measured characters were lower in the alpine zone and on poor substrate than in the subalpine zone and on rich substrate. The substrate-based differences were less evident for calculated characters, whose values usually were lower in the subalpine zone (Figs 3 \& 4).

Multidimensional grouping in discriminant analysis clustered together the samples from the Western Carpathians, Northern and Central Alps and Dinaric Alps, regardless of substrate type or altitude. The Pyrenean samples also clustered together except for sample P1, which joined the Alpine-Carpathian group, and the population from the Western Alps took a position between those two groups. The samples from the Western Scandinavia and the Southern Carpathians were the most distant (Fig. 5). The first canonical variable described over $37 \%$ of variability and was most strongly correlated with $\mathrm{ln} / \mathrm{stl}, \mathrm{bll} / \mathrm{stl}$ and $\mathrm{spl} / \mathrm{stl}$; the second, determining the distinctiveness of the SW sample, was most strongly connected with $b n / f b n$.

\section{DISCUSSION}

Most of the characters were selected specifically for the study, and morphological analyses of the species are scarce, so only a few characters could be compared with other data. The range of values of measured Polygonum viviparum characters in this study was only slightly wider than given in floras and other published data. Stem length varied from 28 to $396 \mathrm{~mm}$ and spike length from 10 to 
Table 4. Results of t-test for two pairs of groups of Polygonum viviparum L.; statistically significant results are bolded; SA - subalpine zone, A - alpine zone; $\mathrm{P}$ - poor granite substrate; $\mathrm{R}$ - calcium-rich substrate, df - degrees of freedom, $\mathrm{p}$ - probability; character acronyms as in Table 2 .

\begin{tabular}{|c|c|c|c|c|c|c|c|c|c|c|}
\hline \multirow{3}{*}{ Character } & \multicolumn{5}{|c|}{ Altitudinal zone } & \multicolumn{5}{|c|}{ Substrate type } \\
\hline & \multicolumn{2}{|c|}{ Mean } & \multirow{2}{*}{$\mathrm{t}$} & \multirow{2}{*}{ df } & \multirow{2}{*}{$\mathrm{p}$} & \multicolumn{2}{|c|}{ Mean } & \multirow{2}{*}{$\mathrm{t}$} & \multirow{2}{*}{$\mathrm{df}$} & \multirow{2}{*}{$\mathrm{p}$} \\
\hline & SA & A & & & & $\mathrm{R}$ & $\mathrm{P}$ & & & \\
\hline stl & 176.00 & 121.48 & 12.3944 & 581 & 0.0000 & 155.10 & 125.52 & 6.18888 & 581 & 0.0000 \\
\hline $\ln$ & 2.45 & 2.89 & -8.1545 & 581 & 0.0000 & 2.84 & 2.54 & 5.47540 & 581 & 0.0000 \\
\hline ull & 19.73 & 16.06 & 4.4778 & 558 & 0.0000 & 19.28 & 14.74 & 5.60918 & 558 & 0.0000 \\
\hline$u l w$ & 2.53 & 2.09 & 3.0415 & 558 & 0.0025 & 2.51 & \begin{tabular}{|l|}
1.88 \\
\end{tabular} & 4.46482 & 558 & 0.0000 \\
\hline bll & 30.80 & 28.49 & 2.6061 & 581 & 0.0094 & 32.83 & 24.34 & 10.41545 & 581 & 0.0000 \\
\hline$b l w$ & 5.95 & 5.49 & 1.8742 & 581 & 0.0614 & 6.24 & 4.84 & 5.78162 & 581 & 0.0000 \\
\hline$b l p$ & 11.23 & 9.07 & 3.2643 & 510 & 0.0012 & 10.63 & 8.71 & 2.88858 & 510 & 0.0040 \\
\hline $\ln / s t l$ & 0.02 & 0.03 & -13.6097 & 581 & 0.0000 & 0.02 & 0.02 & -2.11908 & 581 & 0.0345 \\
\hline $\mathrm{ull} / \mathrm{stl}$ & 0.12 & 0.14 & -3.7322 & 578 & 0.0002 & 0.14 & 0.13 & 1.65714 & 578 & 0.0980 \\
\hline ull/ulw & 8.96 & 8.53 & 1.3733 & 571 & 0.1702 & 8.83 & 8.51 & 1.00702 & 571 & 0.3144 \\
\hline $\mathrm{bll} / \mathrm{stl}$ & 0.18 & 0.26 & -9.7525 & 580 & 0.0000 & 0.24 & 0.21 & 3.48068 & 580 & 0.0005 \\
\hline bll/blw & 6.23 & 6.22 & 0.0067 & 580 & 0.9947 & 6.28 & 6.15 & 0.47234 & 580 & 0.6369 \\
\hline blp/bllp & 0.25 & 0.24 & 1.2840 & 510 & 0.1997 & 0.24 & 0.26 & -1.55005 & 510 & 0.1217 \\
\hline spl & 41.19 & 30.54 & 10.5997 & 581 & 0.0000 & 37.51 & 30.74 & 6.38919 & 581 & 0.0000 \\
\hline$s p-b l$ & 35.18 & 24.39 & 11.4351 & 575 & 0.0000 & 30.59 & 26.02 & 4.46539 & 575 & 0.0000 \\
\hline$f n$ & 7.12 & 7.00 & 0.1417 & 581 & 0.8874 & 8.49 & 4.91 & 4.28662 & 581 & 0.0000 \\
\hline$b n$ & 31.19 & 24.56 & 7.0478 & 581 & 0.0000 & 28.52 & 25.24 & 3.38571 & 581 & 0.0008 \\
\hline$f b n$ & 38.31 & 31.56 & 6.5722 & 581 & 0.0000 & 37.02 & 30.15 & 6.70798 & 581 & 0.0000 \\
\hline $\mathrm{spl} / \mathrm{stl}$ & 24.46 & 26.35 & -3.0278 & 581 & 0.0026 & 25.51 & 25.72 & -0.33187 & 581 & 0.7401 \\
\hline$b n / f b n$ & 0.84 & 0.80 & 1.8674 & 581 & 0.0623 & 0.79 & 0.86 & -3.64666 & 581 & 0.0003 \\
\hline$b n / s p b l$ & 0.90 & 1.06 & -6.0347 & 575 & $\mathbf{0 . 0 0 0 0}$ & 0.98 & 1.01 & -1.07756 & 575 & 0.2817 \\
\hline $\mathrm{fbn} / \mathrm{spl}$ & 0.94 & 1.07 & -5.5848 & 581 & 0.0000 & 1.03 & 1.00 & 1.45956 & 581 & 0.1450 \\
\hline
\end{tabular}

84; European literature data gives $50-400 \mathrm{~mm}$ and 20-75 $\mathrm{mm}$ respectively (Pawłowski 1956; Webb \& Chater 1964; Villar 1990; Bauert 1993). The number of bulbils ranged from 2 to 86 ; in other studies that number fluctuates around 20-40 (Wookey et al. 1994; Totland \& Nyléhn 1998; Gugerli \& Bauert 2001). The differences probably are attributable to the large and multi-sourced pool of samples used in this study.

\section{BIOGEOGRAPHIC STRUCTURE}

Although many aspects of Polygonum viviparum have been examined there has been no phylogeographic analysis of it, so the similarities between regions found in my work can be compared only with general findings on postglacial migrations. The closeness of the $P$. viviparum populations from the Northern and Central Alps well fits the division of the Alps obtained from phylo- geographic studies and with the posited distribution of glacial refugia (Schönswetter et al. 2005). Previous studies on the biogeography of the Alps showed the division of the massif into western and central-eastern parts, the latter further divided into central and eastern parts, evident on both interspecific and intraspecific levels (Schönswetter et al. 2005, Thiel-Egenter et al. 2011). Studies have also suggested that the phylogeographic structure of Alpine plant species is associated with substrate (Alvarez et al. 2009), the distribution of bedrock types and refugia on the margins of the Alps (Schönswetter et al. 2005). However, interspecific differentiation on the molecular level between the western and central-eastern parts of the massif has been found in plant species bound to siliceous, calcareous and intermediate substrate (Alvarez et al. 2009). This may explain the evident distance between 
Table 5. Results of nested ANOVA of Polygonum viviparum characters ( $\%$ - percentage of total variance, $\mathrm{SS}$ - sum of squares, MS - mean square, df - degrees of freedom, F - F statistics, Prob $>$ F - probability).

\begin{tabular}{|c|c|c|c|c|c|c|c|}
\hline Character & Component & $\%$ & SS & MS & $\mathrm{df}$ & $\mathrm{F}$ & Prob $>$ F \\
\hline \multirow[t]{3}{*}{ bll } & between regions & 20.511 & 13648.90 & 2274.810 & 6 & 3.9377 & $0.0439^{*}$ \\
\hline & between samples in regions & 12.067 & 4963.44 & 709.063 & 7 & 8.9541 & $<00001^{*}$ \\
\hline & within samples & 67.423 & 44979.10 & 79.1886 & 568 & & \\
\hline \multirow[t]{3}{*}{$b l w$} & between regions & 27.197 & 1227.07 & 204.5110 & 6 & 6.4158 & $0.0113^{*}$ \\
\hline & between samples in regions & 8.222 & 271.196 & 38.7423 & 7 & 6.6580 & $<0.0001^{*}$ \\
\hline & within samples & 64.581 & 3305.12 & 5.81887 & 568 & & \\
\hline \multirow[t]{3}{*}{ blp } & between regions & 18.441 & 4734 & 789.000 & 6 & 5.6646 & $0.0151^{*}$ \\
\hline & between samples in regions & 5.3 & 1107.98 & 158.283 & 7 & 3.6233 & $0.0008^{*}$ \\
\hline & within samples & 76.26 & 21711.4 & 43.685 & 497 & & \\
\hline \multirow[t]{3}{*}{$u l l / s t l$} & between regions & 10.172 & 0.29666 & 0.04944 & 6 & 3.6261 & $0.0486^{*}$ \\
\hline & between samples in regions & 5.329 & 0.11236 & 0.01605 & 7 & 3.7810 & $0.0005^{*}$ \\
\hline & within samples & 84.499 & 2.39865 & 0.00425 & 565 & & \\
\hline \multirow[t]{3}{*}{ spl/stl } & between regions & 26.503 & 8014.83 & 1335.8 & 6 & 5.5190 & $0.0178^{*}$ \\
\hline & between samples in regions & 9.939 & 2072.03 & 296.004 & 7 & 7.9502 & $<0.0001^{*}$ \\
\hline & within samples & 63.557 & 21147.9 & 37.2323 & 568 & & \\
\hline \multirow[t]{3}{*}{$b n / s p b l$} & between regions & 18.907 & 9.71695 & 1.61949 & 6 & 6.1809 & $0.0113^{*}$ \\
\hline & between samples in regions & 5.116 & 2.15709 & 0.30816 & 7 & 3.9505 & $0.0003^{*}$ \\
\hline & within samples & 75.976 & 43.838 & 0.078 & 562 & & \\
\hline
\end{tabular}

samples from the Central and the Western Alps in my research.

Relationships between the Alpine and the Western Carpathian plant populations have been described for several species as proof of a shared postglacial origin (Zhang et al. 2001; Kropf et al. 2003, 2006). The clustering of the samples from the Central Alps and Western Carpathians in my discriminant analysis (Fig. 5) might therefore be interpreted as resulting from their origin in a common refugium.

Likewise, the Alps and mountains in Western Scandinavia were connected with the migration routes of several species (Schönswetter et al. 2003; Alsos et al. 2009). In my study the samples from the Alps and the Scandinavia grouped with regard to the first discriminant variable (Fig. 5).

During the Pleistocene the Carpathians were far less covered with glaciers than most of the mountain chains of Europe (Kondracki 1978) and could serve as a refugium for alpine plants (Ronikier 2011). Recent phylogeographic studies confirmed the classical biogeographic divisions, with the main boundary between the western and south- eastern parts of the mountains (Ronikier 2011). Thus the observed separateness of the Southern Carpathian sample in my study could be due to protracted isolation of this population.

The overall conclusion is that, in conformity with my working hypothesis, the grouping obtained from discriminant analysis reflects the closeness of samples from regions either geographically close or linked via migration routes despite the differences in altitude and substrate between them. However, molecular studies are needed to confirm the suggestion that the morphological diversity of $P$. viviparum is connected with its postglacial history.

\section{RELATION TO ENVIRONMENTAL FACTORS}

The influence of altitude on some characters of Polygonum viviparum has been described by other authors for particular massifs (Bauert 1993; Totland \& Nyléhn 1998). This study of the whole European geographic range confirmed the decrease of most measured characters with increasing altitude (Fig. 3). Such is common among arctic plants (Fabbro \& Körner 2004) and is interpreted as an 
adaptation to harsh alpine conditions. What may be puzzling is that the effect of altitude on characters differed dramatically between substrate types: biggest leaf width $(b l w)$, length of petiole of biggest leaf $(b l p)$ and number of flowers $(f n)$ decreased with altitude on the calcium-rich substrate (LS) but increased on granite (GR) (Fig. 3). Was this result influenced by the location of the samples? Only two samples collected on granite in the subalpine zone originated from the Central Alps, so the results might be specific to that massif (Fig. 1). An analysis of all altitude groups on all types of substrate in one mountain range probably would yield a reliable answer but that was not the design of this study. Note that the dependence of bulbil production on environmental factors has been reported (Law et al. 1983; Bauert 1993).

The present results did confirm some clear relations between $P$. viviparum characters and substrate type. Most of the measured characters reached higher values for plants from limestone substrate than for those from granite, the only exceptions being number of leaves $(l n)$ and biggest leaf petiole (blp) in the alpine zone (Fig. 2). Previous analyses have pointed out the influence of substrate type on species biodiversity, migration, and the possibility of survival in refugia for a population of a species with specific substrate requirements (Schönswetter et al. 2005; Arnesen et al. 2007; Alvarez et al. 2009); in general, biodiversity is greater on limestone (Wohlgemuth \& Gigon 2003).

The results also demonstrated the greater stability of calculated characters than measured characters. The greater reliability of calculated characters versus morphological traits has been noted in different species (Kremer et al. 2002; Marcysiak 2012c).

\section{VEGETATIVE VERSUS GENERATIVE REPRODUCTION}

Vegetative reproduction is of key importance for the survival of plants in difficult high mountain and arctic conditions; more than $50 \%$ of species occurring there reproduce that way (de Witte et al. 2012). So far the results on a shift to vegetative or sexual reproduction, which in the case of $P$. vivi-

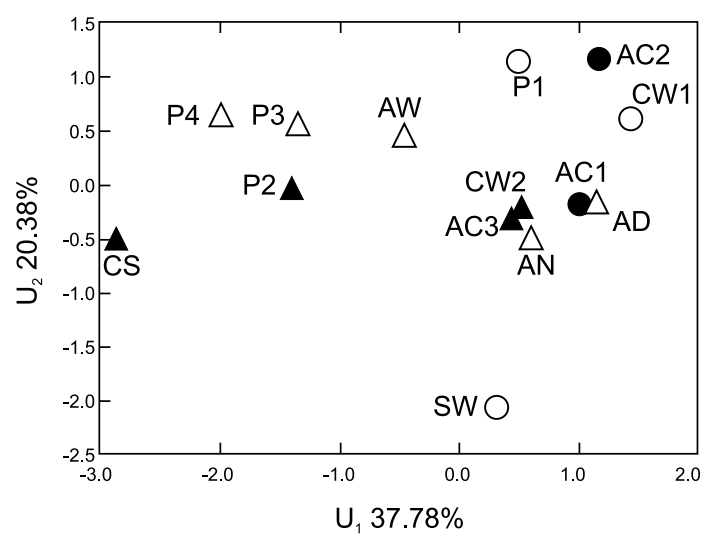

Fig. 5. Results of discriminant analysis for Polygonum viviparum L. samples - means of samples on the plane of the first two variables; triangles - alpine zone, circles - subalpine zone, black - samples collected from poor granite substrate, white - samples collected from calcium-rich substrate. For abbreviations see Table 1 .

parum means increased production of bulbils or flowers, are equivocal. Studies of material from the Alps indicated a decrease of sexual reproduction with increasing altitude (Bauert 1993), while results from Norway and the Qinghai-Tibet Plateau showed the opposite trend (Law 1983; Fan \& Yang 2009). In my work these relations look different on different substrates, but as mentioned already only two samples from granite substrate and the subalpine zone originated from the Central Alps. Perhaps the declining role of sexual reproduction with increasing elevation is typical for the Alps, in accordance with previous findings (Bauert 1993), or perhaps it is connected with granite substrate.

The morphological differentiation of Polygonum viviparum in Europe is determined genetically but also depends on environmental factors, among which altitude and substrate fertility play important roles. Substrate type may also influence the shift between vegetative and generative reproduction. Environmental conditions connected with substrate had less of an effect on the calculated characters that describe the shape of the plant.

ACKNOWLEDGMENTS. I am grateful to Anna Ronikier and Michat Ronikier for their help with collection of material from the Parâng Mts and Dinaric Alps, Agnieszka Biernacka, Katarzyna Stasiewska and Anna 
Wojciechowska for their help with measurements, and to Professor Adam Boratyński and the anonymous reviewer for helpful suggestions on the manuscript. The study was funded in part by Kazimierz Wielki University (Bydgoszcz, Poland).

\section{REFERENCES}

Alsos I. G., Alm T., Normand S. \& Brochmann C. 2009. Past and future range shifts and loss of diversity in Dwarf Willow (Salix herbacea L.) inferred from genetics, fossils, and modelling. Global Ecology and Biogeography 18(2): 223-239.

Alvarez N., Thiel-Egenter C., Tribsch A., HolderegGer R., Manel S., Schönswetter P., Taberlet P., Brodbeck S., Gaudeul M., Gielly L., KüPfer P., MaNSiOn G., Negrini R., PAun O., Pellecchia M., RiouX D., SChÜPfER F., VAN LOO M., WinKLER M., GUGERLi F. \& INTRABIODIV CONSORTIUM. 2009. History or ecology? Substrate type as a major driver of spatial genetic structure in Alpine plants. Ecological Letters 12: 632-640.

ARNESEN G., BECK P. S. A. \& ENGELSKJŘN T. 2007. Soil acidity, content of carbonates, and available phosphorus are the soil factors best correlated with alpine vegetation: evidence from Troms, North Norway. Arctic, Antarctic and Alpine Research 39(2): 189-199.

BAUERT M. R. 1993. Vivipary in Polygonum viviparum: an adaptation to cold climate? Nord. J. Bot. 13: 473-480.

BAUERT M. R 1996. Genetic diversity and ecotypic differentiation in arctic and alpine populations of Polygonum viviparum. Arctic Alpine Res. 28(2): 190-195.

CHAPIN III F. S. 1983. Direct and indirect effects of temperature on Arctic plants. Polar Biol. 2: 47-52.

De Witte L. C., Armbruster G. F. J., Gielly L., Taberlet P. \& STÖCKLIN J. 2012. AFLP markers reveal high clonal diversity and extreme longevity in four key arctic-alpine species. Molecular Ecology 21: 1081-1097.

DigGLE P. K. 1997. Extreme preformation in alpine Polygonum viviparum: an architectural and developmental analysis. Amer. J. Bot. 84(2): 154-169.

Diggle P. K., Lower S.\& RANKer T. A.. 1998. Clonal diversity in alpine populations of Polygonum viviparum (Polygonaceae). Int. J. Pl. Sci. 159(4): 606-615.

Diggle P. K., Meixner M. A., Carroll A. B. \& AschwanDEN C. F. 2002. Barriers to sexual reproduction in Polygonum viviparum: a comparative developmental analysis of P. viviparum and P. bistortoides. Ann. Bot. 89: 145-156.

Dormann C. F., Albon S. D. \& Woodin S. J. 2002. No evidence for adaptation of two Polygonum viviparum morphotypes of different bulbil characteristics to length of growing season: abundance, biomass and germination. Polar Biol. 25: 884-890.
FABBRO T. \& KÖRNER C. 2004. Altitudinal differences in flower traits and reproductive allocation. Flora 199: 70-81.

FAN D. M. \& YANG Y. P. 2009. Altitudinal variations in flower and bulbil production of an alpine perennial, Polygonum viviparum L. (Polygonaceae). Plant Biol. 11: 493-497.

Gugerli F. \& BAuerT M. R. 2001. Growth and reproduction of Polygonum viviparum show weak responses to experimentally increased temperature at a Swiss Alpine site. Bot. Helvet. 111: 169-180.

KONDRACKI J. 1978. Karpaty. Wydawnictwa Szkolne i Pedagogiczne. Warszawa.

Kremer A., Dupouey J. L., DeAns J. D., Cottrell J., CsAIKL U., FINKELDEY R., ESPINEL S., JENSEN J., KLEINSCHMIT J., VAN DAM B., DuCOUSSO A., FORREST I., LOPEZ de Heredia U., Lowe A. J., Tutkova M., Munro R. C., STEINHOFF, S. \& BADEAU V. 2002. Leaf morphological differentiation between Quercus robur and Quercus petraea in stable across Western European mixed oak stands. Annals of Forest Science 59: 777-787.

Kropf M., Kadereit J. W. \& COMES H. P. 2003. Differential cycles of range contraction and expansion in European high mountain plants during the Late Quaternary: insights from Pritzelago alpina (L.) O. Kuntze (Brassicaceae). Molecular Ecology 12: 931-949.

Kropf M., COMES H. P. \& KADEREIT J. W. 2006. Long-distance dispersal vs vicariance: the origin and genetic diversity of alpine plants in the Spanish Sierra Nevada. New Phytol. 172: 169-184.

LAW R., CoOK R. E. D. \& Manlove R. J. 1983. The ecology of flower and bulbil production in Polygonum viviparum. Nord. J. Bot. 3(5): 559-566.

MARCYSIAK K. 2012a. Variation of leaf shape of Salix herbacea in Europe. Pl. Syst. Evol. 298: 1597-1607.

MARCYSIAK K. 2012b. Diversity of Salix reticulata L. (Salicaceae) leaf traits in Europe and its relation to geographical position. Plant Biosystems 146(Suppl. 1): 101-111.

MARCYSIAK K. 2012c. Calculated characters of leaves are independent on environmental conditions in Salix herbacea (Salicaceae) and Betula nana (Betulaceae). Acta Soc. Bot. Poloniae 81(3): 153-158.

PAWŁOWSKi B. 1956. Flora Tatr. 1. Państwowe Wydawnictwo Naukowe, Warszawa.

RONIKIER M. 2011. Biogeography of high-mountain plants in the Carpathians: An emerging phylogeographical perspective. Taxon 60(2): 373-389.

Schönswetter P., Paun O., Tribsch A. \& Niklfeld H. 2003. Out of the Alps: colonization of Northern Europe by east alpine populations of the glacier buttercup Ranunculus glacialis L. (Ranunculaceae). Molecular Ecology 15: 709-720.

SChÖNSwetter P., STEhlik I., Holderegger R. \& TRIB$\mathrm{SCH}$ A. 2005. Molecular evidence for glacial refugia of 
mountain plants in the European Alps. Molecular Ecology 14: $3547-3555$.

SCHÖNSWETter P., SUdA J., POPP M., WeISS-SCHNEEWEISS H. \& BROCHMANN CH. 2007. Circumpolar phylogeography of Juncus biglumis (Juncaceae) inferred from AFLP fingerprints, cpDNA sequences, nuclear DNA content and chromosome numbers. Molec. Phylogenet. Evol. 42: 92-103.

Skrede I., Bronken E. P., Pineiro P. R. \& Brochman Ch. 2006. Refugia, differentiation and postglacial migration in arctic-alpine Eurasia, exemplified by the mountain avens (Dryas octopetala L.). Molecular Ecology 15 (7): 1827-1840.

SoKAL R. R. \& RohlF F. J. 2003. Biometry. $3^{\text {rd }}$ ed. W. H. Freeman and 720 Company, New York.

Thiel-Egenter C., Alvarez N., Holderegger R., TribSCh A., Englisch T., Wohlgemuth T., Colli L., GaUDEUl M., Gielly L., JOGAN N., Linder H P., NEGRINI R., Niklfeld H., Pellecchia M., RiouX D., SchÖNSWetTER P., TABERlet P., VAN LOO M., WinKLER M., INTRABioDiv CONSORTIUM \& GUGERLi F. 2011. Break zones in the distributions of alleles and species in alpine plants. J. Biogeogr. 38: 772-782.

Tomita M. \& Masuzawa T. 2010. Reproductive mode of Polygonum viviparum depends on environment. Polar Science 4: 62-70.

TotLand Ø. \& NYLÉHN J. 1998. Assessment of the effects of environmental change on the performance and density of Bistorta vivipara: the use of multivariate analysis and experimental manipulation. J. Ecol. 86: 989-998.

Villar L. 1990. Polygonum. In: S. Castroviejo, M. Lainz, G. L. GonzÁlez, P. MontSERrat, F. MuŇOZ GARMENDiA, J. PAIVA \& L. Villar (eds), Flora Iberica. 2: 571-586. Real Jardín Botánico, Madrid.

WeBb D.A. \& Chater A.O. 1964. Polygonum. In: T. G. Tutin, V. H. Heywood, N. A. Burge, D. H. Valentine, S. M. WALters \& D. A. WeBB (eds), Flora Europaea. 1: 76-80. Cambridge University Press, Cambridge.

Wohlgemuth T. \& GigON A. 2003. Calcicole plant diversity in Switzerland may reflect a variety of habitat templets. Folia Geobot. 38: 443-452.

Wookey P. A., Welker J. M., Parsons A. N., Press M. C., Callaghan T. V. \& LeE J. A. 1994. Differential growth, allocation and photosynthetic responses of Polygonum viviparum to simulated environmental change at a high arctic polar semi-desert. Oikos 70: 131-139.

ZAJĄC M. \& ZAJĄC A. 2009. The geographical elements of native flora of Poland. Edited by Laboratory of Computer Chorology, Institute of Botany, Jagiellonian University, Kraków.

Zhang L.-B., Comes H. P. \& Kadereit J. W. 2001. Phylogeny and Quaternary history of the European montane/alpine endemic Soldanella (Primulaceae) based on ITS and AFLP variation. Amer. J. Bot. 88(12): 2331-2345. 